\title{
EFFEKTIVITAS SANKSI PIDANA DALAM PENEGAKAN HUKUM LINGKUNGAN
}

\author{
Sahat Maruli T. Situmeang \\ Fakultas Hukum Universitas Komputer Indonesia \\ sahat@email.unikom.ac.id
}

\begin{abstract}
Application sanctions for the perpetrators of environmental crime whether committed by individuals and carried out by the corporation can be executed by means of administrative law, civil law or through criminal law. Of some sanctions in its application should be through a thorough and careful assessment in accordance with the characteristics, objectives and benefits of the application of sanctions. In this study, the authors conducted a study on the application of sanctions for perpetrators of environmental crimes, either in the form of administrative sanctions, and sanctions in the form of a court decision which is done through a civil action or criminal sanctions proposed by puitusan court investigator, so they will know particularly the effectiveness of any sanctions to be imposed criminal sanctions against the perpetrators of environmental crimes. The research method used in this research using normative juridical research method, by studying legal norms that exist that can be used as a guide for the implementation of laws that already exist. Through this study, the researcher has an opinion that the sanctions that are considered most effective to be applied to the perpetrators of environmental crime and the enforcement of environmental laws, namely by means of administrative law with the form of sanctions to freeze and / or revoke the business license of each corporation who have committed crimes environment.

Keywords: Environmental Crimes, Penalties Law, Environmental Law Enforcement
\end{abstract}

\section{ABSTRAK}

Penegakan hukum bagi para pelaku kejahatan lingkungan hidup telah diatur dalam bentuk sanksi sebagaimana yang telah dimuat dalam Undang-undang Nomor 32 Tahun 2009 Tentang Perlindungan dan Pengelolaan Lingkungan Hidup. Penerapakan sanksi bagi para pelaku kejahatan lingkungan hidup baik yang dilakukan oleh perorangan maupun yang diakukan oleh korporasi dapat dijalankan melalui sarana hukum adminstrasi, hukum perdata maupun melalui hukum pidana. Dari beberapa sanksi yang telah diatur dalam Undang-undang Nomor 32 Tahun 2009 ters ebut dalam penerapannya haruslah melalui suatu kajian secara seksama dan cermat sesuai dengan karakteristik, tujuan dan manfaat dari penerapan sanksi tersebut. Penelitian ini bertujuan untuk mengetahui efektifitas dari suatu sanksi, terlebih sanksi pidana yang akan dijatuhkan terhadap para pelaku kejahatan lingkungan hidup melalui metode penelitian yuridis normatif, yaitu dengan mempelajari norma-norma hukum yang ada yang dapat digunakan sebagai suatu panduan untuk terlaksananya undang-undang yang telah ada. Melalui penelitian ini, peneliti memiliki suatu pendapat bahwa penerapan sanksi yang dianggap paling effektif untuk diterapkan bagi para pelaku kejahatan lingkungan hidup dan dalam rangka penegakan hukum lingkungan yaitu melalui sarana hukum administrasi dengan bentuk sanksi membekukan dan/atau mencabut ijin usaha setiap korporasi yang melakukan kejahatan lingkungan. Kata kunci : Kejahatan Lingkungan Hidup, Sanksi Hukum, Penegakan Hukum Lingkungan

\section{PENDAHULUAN}

Menurunnya kesadaran pemeliharaan tempat tinggal akan memberi dampak yang buruk terhadap kehidupan masyarakat dan alam sekitar. Hal ini terjadi karena masyarakat memiliki tingkat kesadaran yang buruk sebagai manusia yang seharusnya berperan sebagai pemelihara lingkungan hidupnya dan alam sekitar tempat tinggalnya. Hal inilah yang dinilai masih sangat perlu untuk dibenahi dalam menjaga kualitas hidup dan alam. Pemanfaatan yang berlebihan terhadap alam, akan menyebabkan kerusakan yang parah dan masyarakat enggan untuk memperbaiki dan merawatnya sebagaimana seharusnya. Eksploitasi terhadap alam yang terjadi secara terus-menerus akan semakin memperparah 
kerusakan yang ada dan membutuhkan waktu yang sangat lama untuk memperbaikinnya kembali. Semakin parah kerusakan maka akan semakin tidak layak untuk ditinggali oleh manusia, karena dampak buruknya akan dirasakan langsung oleh manusia itu sendiri. Manusia memiliki peranan penting dalam pemanfaatan dan pemeliharaan alam, karena hanya manusia lah yang dapat melakukan hal tersebut sebagai satu-satunya makhluk yang memiliki akal. ${ }^{1}$ Dalam hal ini Peran manusia sebagai masyarakat merupakan bagian penting dalam pengelolaan lingkungan hidup, Sherry R. Arnstein menyebutkan bahwa tingkat tertinggi dalam peran serta pengelolaan lingkungan hidup adalah kontrol oleh masyarakat (citzen control) $^{2}$.

Kesalahan yang ada dalam hal pemanfaatan sumber daya alam, semestinyalah penegakan peraturan yang ada dalam hal ini oleh para pelaku telah dilanggar haruslah diberikan sanksi yang setimpal dengan apa yang telah diperbuatnya. Dewasa ini, kebijakan penggunaan sanksi pidana lebih sering digunakan untuk dapat mengatur serta mentertibkan masyarakat melalui berbagai macam peraturan perundang-undangan yang telah ada ${ }^{3}$.

Penjelasan umum Undang-Undang Nomor 32 Tahun 2009 tentang Perlindungan dan Pengelolaan Lingkungan Hidup menyatakan bahwa penegakan hukum pidana lingkungan tetap memperhatikan asas ultimum remidium yang mewajibkan penerapan penegakan hukum pidana sebagai upaya terkahir setelah penerapan penegakan hukum administratif dianggap tidak berhasil. Istilah ultimum remidium menurut menteri Kehakiman Belanda, Mr. Modderman yang menyatakan bahwa yang dapat dihukum, pertama adalah pelanggaran-pelanggaran hukum ini merupakan akibat yang dapat ditentukan sebab-sebabnya dan masing-masing sebab memiliki pengaruh terhadap terjadinya suatu akibat. Pada dasarnya suatu hukuman tidak bisa

dihilangkan, namun dalam ketentuannya tetaplah hukuman pidana itu digunakan sebagaya upaya terkahir ${ }^{4}$.

Berbicara mengenai sanksi, berarti haruslah ada subjek hukum yang melanggar peraturan perundang-undangan atau peraturan tertulis lainnya, dalam hal ini peneliti menitikberatkan terhadap pertanggungjawaban korporasi sebagai subjek hukum terhadap perusakan lingkungan atau pencemaran lingkungan. Menurut Ismid CSJ ada beberapa macam dari pengerusakan sumber daya alam di indonesia salah satunya disebabkan oleh kebijakan-kebijakan sektoral dan ekspolitasi yang berlebih dalam pengelolaan sumber daya alam $^{5}$. Pertanyaan yang paling mendasar dalam penelitian ini adalah mengapa peneliti lebih memilih pertanggungjawaban korporasi sebagai subjek hukum dalam melihat efektifitas sanksi pidana dalam penegakan hukum lingkungan, karena hampir semua pelanggaran terhadap hukum lingkungan yang ada dilakukan oleh dan untuk menguntungkan korporasi ${ }^{6}$.

\section{METODE PENELITIAN}

1 Indonesia Center For Enviromental Law (ICEL) dan Pusat Pendidikan dan Pelatihan Teknis Peradilan Mahkamah Agung, Republik Indonesia, 2014.

${ }^{2}$ Sherry Arnstein, Ladder of Citizen Participation, Journal Of the Amrican Institute of Palnners, November, 2007.

${ }^{3}$ Indonesian Center For Enviromental Law (ICEl), Op. Cit.

4 P.A.F Lamintang dikutip dalam Widayati, Lidya Suryani. "Ultimum Remedium dalam Bidang Lingkungan Hidup." Jurnal Fakultas Hukum UII 22.1 (2015): 1-24.

5 Slamet Suhartono "Corporate Responsibility For Environmental Crime In Indonesia." Journal of Law and Conflict Resolution 9.1 (2017): 1-8.

6 Andri G. Wibisana "Kejahatan Lingkungan Oleh Korporasi: Mencari Bentuk Pertanggungjawaban Korporasi Dan Pemimpin/Pengurus Korporasi Untuk Kejahatan Lingkungan Di Indonesia?." Jurnal Hukum \& Pembangunan 46.2 (2016): 149-195. 
Penelitian yang dilakukan bersifat yuridis normatif, yaitu dengan melakukan analisis terhadap permasalahan hukum melalui norma-norma hukum yang termuat dalam peraturan perundang-undangan di Indonesia. Penelitian ini merupakan penelitian hukum doktrinal, karena yang dikaji adalah doktrin-doktrin, prinsip serta kaidah hukum yang tertulis dalam bukum maupaun keputusan hakim di pengadilan. Tipologi penelitian ini bersifat deskriptif analisis yang bertujuan untuk menggambarkan, menginventarisir, dan menganalisis kondisi yang sebenarnya tentang perkembangan hukum yang berkaitan dengan efektivitas sanksi pidana dalam hukum lingkungan di Indonesia. Data sekunder yang digunakan dalam penelitian ini dikumpulkan dari sumber primer berupa perundangundangan. Data yang sudah terkumpul akan dianalisis dengan penelaahan terhadap peraturan perundang - undangan hukum Indonesia.

\section{PEMBAHASAN}

\section{Pencemaran dan Perusakan Lingkungan Hidup}

Definisi lingkungan hidup menurut Undang-Undang PPLH menyebutkan bahwa :

"Lingkungan Hidup adalah kesatuan ruang dengan semua benda, daya, keadaan, dan makhluk hidup, termasuk manusia, dan perilakunya, yang mempengaruhi kelangsungan perikehidupan dan kesejahteraan manusia serta makhluk hidup lain dan dapat mempengaruhi hidupnya".

Pengertian lingkungan hidup yang lebih menurut Undang-Undang PPLH adalah kesatuan ruang dengan semua benda atau kesatuan makhluk hidup termasuk di dalamnya ada manusia dan segala tingkah lakunya demi melangsungkan perikehidupan dan kesejahteraan manusia maupun makhluk hidup lainnya yang ada disekitarnya. Undang-Undang PPLH menyatakan bahwa perlindungan lingkungan hidup adalah upaya sistematis dan terpadu yang dilakukan untuk melestarikan fungsi lingkungan. karena pada dasarnya perlindungan lingkungan hidup bukanlah suatu kemewahan yang hanya dapat dilakukan oleh negara maju?

Pencemaran dan peruskan lingkungan merupakan bahya yang senantiasa mengancam kehidupan dari waktu ke waktu, ekosistem dari suatu lingkungan dapat terganggu kelestariannya karena pencemaran dan perusakan lingkungan. Istilah pencemaran dan perusakan lingkungan hidup seringkali diacmpuradukan, padahal keduanya memiliki realitas sendiri-sendiri, sebagai berikut :

- Pencemaran lingkungan adalah masuk atau dimasukkannya makhluk hidup, zat, energi, atau komponen lain ke dalam lingkungan hidup oleh kegiatan manusia sehingga melampaui baku mutu lingkungan hidup yang diterapkan.

- Perusakan lingkugan hidup merupakan tindakan yamng dilakukan oleh seseorang yang dapat mnenimbulkan perubahan baik langsung maupun tidak langsung terhadap sifat fisik, kimia, dan/atau kerusakan pada lingkungan hidup.

\footnotetext{
${ }^{7}$ Jean B. Aden, "The relevance of environmental protection in Indonesia." Ecology LQ 4
} (1974): 987. 
Perbedaan mengenai pencemaran dan perusakan lingkungan hidup pada dasarnya memang tidak terlalu mendasar karena setiap orang yang melakukan perusakan lingkungan, bearti ia juga telah melakukan pencemaran lingkungan ataupun sebaliknya. Perbedaan dari keduanya hanya terletak pada tingkat keseriusan perbuatan yang dilakukan terhadap lingkungan dan intensitas perbuatan yang dilakukan terhadap lingkungan dan kadar akibat yang diderita oleh lingkungan hidup akibat perbuatan tersebut. Istilah pencemaran digunakan untuk melukiskan bagaimana keadaan alam yang lebih berat dari sekedar pengotoran bvelaka, dalam perkembangannya istilah pencemaran lingkungan mengalami kekhususan sebagaimana berikut ${ }^{8}$ :

"Pencemaran air, pencemaran daratan, pencemaran udara, pencemaran angkasa dab lain-lain. Pencemaran lingkungan menimbulkan kerugian yang dapat terjadi dalan bentuk kerugian ekonomi dan sosial, serta gangguan sanitair".

Definisi Perusakan Lingkungan hidup menurut Pasal 1 ayat 16 UndangUndang PPLH menyebutkan bahwa :

"Perusakan lingkungan hidup diartikan sebagai tindakan orang yang menimbulkan perubahan langsung dan/atau tidak langsung terhadao sifat fisik, kimia, dan/atau hayati lingkungan hidup yang melampaui kriteria baku kerusakan lingkungan hidup".

Perusakan lingkungan hidup berarti bahwa lingkungan tidak dapat dimanfaatkan lagi sebagimana fungsi yang sebenarnya, dengan rusaknya suatu lingkungan maka akan semakin berkurang kegunaannya atau dengan kata lain mendekati kepunaham, atau mungkin bahkan telah punah. Rusaknya lingkungan dapat terjadi karena adanya perbuatan manusia. Keruskan lingkungan hidup merupakan masalah yang lingkungan yang cukup serius, apabila kita pahami secara seksama bahwa lingkungan hidup yang baik dan sehat adalah hak dasar setiap warga negra Indonesia sebagaimana diatur dalam Pasal 28 H UUD $1945^{9}$.

Pemerintah Indonesia pada dasarnya telah melakukan upaya-upaya untuk dapat mengurangi dampak akibat dari perusakan lingkungan hidup yang tertuang darui berbagi bentuk peraturan perundang-undangan. Dalam hal ini pemerintah telah bersungguh-sungguh dalam menyikapi perusakan lingkungan hidup yang tertuang dalam Undang-Undang Nomor 32 Tahun 2009 tentang Perlindungan dan Pengelolaan Lingkungan Hidup (untuk selanjutnya disebut dengan UU PPLH), mengingat masalah lingkungan hidup berada dalam wilayah hukum publik sehingga pemerintah atau negara memiliki fungsi serta kapasitas dalam membuat kebijakan ataupun perencanaan terhadap sistem dan pengelolaan lingkungan hidup.

\section{Efektivitas Sanksi Pidana Dalam Penegakan Hukum Lingkungan}

Masalah lingkungan hidup bagi manusia dapat dilihat dari segi menurunnya kulaitas lingkungan menyangkut nilai lingkungan untuk kesehatan, kesejahteraan

\footnotetext{
${ }^{8}$ Muhammad Erwin, "Hukum Lingkungan: Dalam Sistem Perlindungan Dan Pengelolaan Lingkungan Hidup Di Indonesia.",Refika Aditama, Bandung, 2015.

9 Agus Widodo, Implementation Of Act No. 32 Of 2009 On Enviromental Management, International Journal of Business, Economic and Law, Vol. 10, Issue 4. 2016.
} 
dan ketentraman manusia. Hilang dan berkurangnya nilai lingkungan karena pemanfaatan tertentu oleh manusia. Menurut Drupsteen masalah lingkungan merupakan kemunduruan kualitas lingkungan yang menyangkut gangguangangguan terhadap lingkungan antara manusia dan lingkungan ${ }^{10}$. Undang-Undang tentang PPLH membagi masalah lingkungan menjadi dua bentuk yaitu Pencemaran Lingkungan dan Perusakan Lingkungan. Masalah yang ditimbulkan dari pencemaran dan perusakan lingkungan dapat terlihat dan dirasakan oleh manusia serta terganggunya keseimbangan sumber daya alam serta rusaknya ekosistem yang mengalami permasalahan lingkungan.

Dalam penjelasan secara umum mengenai undang-undang yang membahas terkait permasalahan mengenai lingkungan yang mana sudah semakin memburuk dan mengancam kehidupan masyarakat dan alam itu sendiri. Ada sebagian undangundang yang memuat permasalahan mengenai lingkungan, sanksi administratif, perdata dan pidana. Ketentuan tersebut menegaskan bahwa subsidaritas dari sanksi yang diberikan terhadap pelanggaran tersebut. Herbert L. Packer menjelaskan dalam bukunya yang berjudul The Limit Of Criminal Sanction, yang membahas tentang suatu pembenaran pidana menyimpulkan bahwa pemberian sanksi pidana adalah salah satu sarana terbaik yang ada untuk dapat menghadapi masalahmasalah yang terjadi ${ }^{11}$. Pendapat dari kaum konsekuensialis mengatakan mengenai pidana dapat dibenarkan apabila hukum pidana tersebut dapat memberikan dampak positif sekaligus dapat mencegah hal-hal yang lebih parah terjadi ${ }^{12}$.

Merujuk pada pembahasan bab terdahulu bahwa sebagaian besar pelaku perusakan lingkungan hidup melibatkan korporasi maka penulis perlu mendalami bahwasannya terdapat pertanggungjawaban korporasi dalam permasalahan lingkungan hidup. Fisse dan Braithwaite membagi tiga hal paling mendasar dalam mewujudkan penegakan hukum yang adil dan efektif bagi kejahatan korporasi, yaitu : Pertama, bagian dari pertanggungjawaban kejahatan korporasi haruslah berdasarkan bahwa tindakan yang dilakukan oleh kororasi tersebut bukanlah semata-mata tindakan yang dilakukan oleh individu melainkan oleh korporasi itu sendiri. Kedua, bahwa pembagian dari pertanggungjawaban kejahatan korporasi dilakukan oleh semua pihak yang terkait. Ketiga, pertanggungjawaban individu harus dihindari agar tidak ada korban dari kejahatan korporasi tersebut ${ }^{13}$.

Sedangkan menurut Sutan, pertanggungjawaban tindak pidana korporasi dapat dilaksanakan jika perbuatan korporasi memenuhi beberapa elemen atau syarat berikut $^{14}$ :

Perbuatan dilakukan dan diperintahkan oleh anggota/personil korporasi yang ada pada struktur organisai korporasi tersebut;

10 Araya, Yulanto. "Penegakan Hukum Lingkungan Hidup di Tengah Pesatnya Pembangunan Nasional." [41] Jurnal Legislasi Indonesia 10.1 (2013).

11 Duff, Antony, and David Garland. "A reader on punishment." (1994). University Press, Oxford.

12 Brent Fisse dan Jhon Braithwaite, Corporations, Crime, and Accountability, Cambridge University Press 1993

${ }_{13}$ Slamet Suhartono, Op. Cit.

14 Amiq, Bachrul., Administratif Sanction In Enviromental Law, International Journal Of Research Granthaalayah, Vol. 6 June 2018. 
a. Perbuatan tindak pidana dilakukan di dalam kerangka kerja dari niatan dan tujuan korporasi tersebut;

b. Tindak pidana dilakukan oleh pelaku atau berdasarkan perintah yang diberikan oleh koporasi;

c. Perbuatan pidana tersebut dilakukan dengan maksud untuk menguntungkan korporasi;

d. Pelaku tidak bisa melepaskan diri dari pertanggungjawaban pidana;

e. Tindak pidana membutuhkan pebuatan dan kesalahan, kedua hal tersebut tidak boleh hanya ditemukan pada satu orang.

Sebagai salah satu contoh kasus yaitu yang terjadi pada PT Stanido Inti Perkasa (SIP) di Bangka Belitung telah terbukti bersalah melanggar UndangUndang Perlindungan dan Pengelolaan Lingkungan Hidup dalam putusannya. Sebagaimana diketahui kasus di Bangka Belitung berawal dari operasi penambangan timah dengan Kapal Isap Produksi (KIP) tak berrizin di kawasan destinasi wisata pantai pasir padi. Perusahaan ini di duga melanggar Pasal 109 Undang-Undang PPLH jo. Pasal 116 ayat (1) huruf a dengan ancaman pidana kurungan maksimal 3 (tiga) tahun dan denda paling banyak Rp. 3.000.000.000.000,00 (tiga miliar rupiah). Namun dalam tuntutan, jaksa tidak menuntut pidana kurungan hanya menuntut pidana denda, sehingga dalam putusannya Pengadilan Negeri Pangkal Pinang hanya memvonis pidana denda sebesar Rp. 1.1000.000.000,00 (satu miliar seratus juta rupiah) tanpa memberikan pidana kurungan terhadap pemilik ataupun pimpinan perusahaan yang telah terbukti secara sah dan meyakinkan melakukan tindak pidana lingkungan hidup. Dalam hal ini masyarakat sekitar menilai bahwa putusan yang telah dijatuhkan oleh Pengadilan Negeri Pangkalpinang belum memenuhi rasa kedalian terhadap masyarakat. Mengingat kerusakan yang ditimbulkan dari aktivitas perusahaan tersebut dapat membuat kerusakan ekosoistem penunjang wilayah pesisir seperti terumbu karang, rumput laut, biota-biota laut bahkan hutan mangrove tidak dapat berkembang dengan baik akibat terjadi degradasi, namun tidak hanya itu penambangan timah dapat mengakibatkan abrasi pesisir dan dapat merusak laut yang ada di dalamnya. Sehingga dapat berpengaruh pula terhadap perekonomian masyarakat sekitar yang mana mata pencahariannya adalah sebagai nelayan.

Bahwa dalam hal ini peniliti berpendapat, sanksi pidana mengenai pertanggungjawaban korporasi dalam masalah lingkungan hidup dan dipandang masih belum efektif dapat menyelesaikan atau mengurangi tindakan pengerusakan belum sepenuhnya dapat dijalankan dengan semestinya, contoh kasus diatas hanyalah sebagian kecil yang terlihat, tindak pidana korporasi mengenai lingkungan hidup seperti halnya fenomena gunung es yang terlihat dipermukaan hanya sebagian kecil sedangkan di dasarnya begitu banyak yang tidak terlihat, Pasal 116 UU PPLH telah sangat tegas menyebutkan bahwa :

(1). Apabila tindak pidana lingkungan hidup dilakukan oleh, untuk, atau atas nama badan usaha, tuntutan pidana dan sanksi pidana dijatuhkan kepada :

a. Badan usaha; dan/atau

b. Orang yang memberi perintah untuk melakukan tindak pidana tersebut atau orang yang bertindak sebagai pemimpin kegiatan dalam tindak pidana tersebut.

(2). Apabila tindak pidana lingkungan hidup sebagaimana dimaksud pada ayat (1) dilakukan oleh orang yang berdasarkan hubungan kerja atau berdasarkan hubungan lain yang bertindak dalam lingkup kerja badan usaha, sanksi pidana 
dijatuhkan terhadap pemberi perintah atau pemimpin dalam tindak pidana tersebut tanpa memperhatikan tindak pidana tersebut dilakukan secara sendiri atau bersama-sama.

Bahkan dalam Pasal 117 UU PPLH memberikan pemberatan pada sanksi yang diberikan apabila tindak pidana lingkungan hidup ditujukan kepada pemberi perintah atau pimpinan yang menyebutkan bahwa :

"jika tuntutan pidana diajukan kepada pemberi perintah atau pemimpin tindak pidana sebagaimana dimaksud dalam Pasal 116 ayat (1) huruf $b$, ancaman pidana yang dijatuhkan berupa pidana penjara dan denda diperberat dengan sepertiga."

Jika melihat ketentuan dalam Undang-Undang PPLH dalam permasalahan tersebut seharusnya Pengadilan Negeri Pangkal Pinang dapat memberikan sanksi semaksimal mungkin baik sanksi pidana maupun sanksi tambahan lainnya agar dapat memberikan efek jera terhadap para pelaku perusakan lingkungan dan juga sekaligus dapat mengurangi terjadinya kerusakan lingkungan yang lebih luas. Apabila sanksi yang dijatuhkan tidak tegas dan tidak memuat sanksi tambahan lainnya berupa denda dan pembekuan atau pencabutan ijin usaha, penulis memandang bahwa koorporasi tidak akan pernah jera, karena masih menganggap putusan hakim yang sedemikian itu tidak akan mengkhawatirkan atau ditakuti oleh korporasi karena tidak akan menimbulkan kerugian yang signifikan bagi perusahaan dan usahanya masih tetap dapat berjalan, dan dari hasil usaha tersebut koorporasi masih memiliki kemampuan untuk menempuh upaya-upaya lainnya, termasuk membayar pidana denda, tanpa harus memikirkan bagaiamana upaya pemulihan lingkungan yang telah rusak karena perbuatannya, sedangkan dampak kerusakan lingkungan dapat terjadi dalam jangka waktu yang sangat lama.

Jika menalaah lebih dalam atas putusan-putusan pengadilan dalam mengadili para pelaku pengrusakan lingkungan melalui penerapan sanksi pidananya cenderung masih mengedepankan asas premium remidium, sedangkan asas yang tersirat dalam Undang-Undang PPLH sangat mengedepankan asas ultimum remedium yang lebih mengedepankan penyelesaian administratif. Jadi sanksi pidana terhadap para pelaku pengrusak lingkungan merupakan upaya atau obat yang terakhir apabila sanski asministratif dan sanksi perdata sudah tidak mungkin lagi diterapkan. Menurut hemat penulis bahwa sanksi administratif bagi koorporasi yang telah melakukan pengrusakan lingkungan akan lebih effektif dibandingkan dengan sanksi perdata dan sanksi pidana, karena sanksi administratif berupa pembekuan dan pencabutan ijin usaha perusahaan akan sangat ditakuti oleh koorporasi, dimana dengan dibekukannya ijin usaha dan atau dicabutnya ijin usaha dari perusahaan pengrusak lingkungan membuat perusahaan tersebut tidak lagi dapat melakukan kegiatan usahanya, sehingga perusahaan tidak akan lagi mendapat pemasukan atau keuntungan dari padanya, dan ini sudah pasti sangat ditakuti oleh setiap koorporasi. Dengan demikian koorporasi akan berpikir dua kali untuk melakukan atau mengulangi melakukan tindakan-tindakan berupa pengrusakan lingkungan. Oleh karenanya, penulis berpendapat bahwa penerapan sanksi pidana bagi koorporasi yang melakukan pengrusakan lingkungan masih dirasakan kurang efektif, karena selain penegakan hukumnya yang kurang juga dibutuhkan penanganan khusus serta memakan waktu yang lama. Adanya kecenderungan untuk melakukan dan atau melakukan kembali perbuatan yang sama sangat tinggi sebagaimana yang sedang terjadi saat ini. 
Setelah membahas dalam bab terdahulu mengenai masalah lingkungan hidup yang menggunakan sanksi pidana dan putusannya dirasakan tidak memberikan rasa keadilan bagi masyrakat penulis berpendapat bahwa sanksi administratif dapatlah diberlakukan terlebih dahulu, karena pada dasarnya penegakan sanksi administratif merupakan bagian dari penegakan hukum lingkungan ${ }^{15}$ Terlebih lagi, dalam menghadapi aktivitas pembangunan yang berkelanjutan yang menjadi salah satu ruh dalam sistem pengelolaan lingkungan hidup, instrumen administrasi lingkungan hidup difungsikan untuk menjamin tertap terpeliharanya kelestarian kemampuan lingkungan hidup, sehingga generasi mendatang tetap memiliki sumber daya alam yang menunjang kesejahteraan dan kualitas kehidupannya.

Selain itu penegakan hukum administrasi memiliki beberapa keuntungan jika dibandingkan dengan penegakan hukum perdata maupun pidana yaitu ${ }^{16}$ :

a. Penegakan hukum administrasi di bidang lingkungan hidup sebagai perangkat pencegahan;

b. Penegakan hukum administrasi (yang bersifat pencegahan tersebut) jika dilihat dari sudut pandang pembiayaan maka hukum administrasi lebih efisien dibandingkan penegakan hukum perdata.Pembiayaan untuk penegakan hukum administrasi meliputi biaya pengawasan lapangan yang dilakukan secara rutin dan pengujian laboratorium lebih murah jika dibandingkan dengan upaya pengumpulan bukti, investigasi lapangan, menghadirkan Ahli untuk membuktikan aspek kausalitas (sebab-akibat) dalam kasus pidana dan perdata;

c. Penegakan hukum administrasi lebih memiliki kemampuan mengundang pasrtisipasi masyarakat. Partisipasi masyarakat dilakukan mulai dari proses perizinan, pemantauan penataan/pengawasan, dan partisipasi dalam mengajukan keberatan dan meminta pejabat tata usaha negara untuk memberlakukan sanksi administratif.

Sanksi administratif adalah satu dari banyak sarana penegakan hukum ${ }^{17}$, pada pelaksanaannya, sering kali sanksi administrasi menyelesaikan suatu tindakan pelanggaran ketentuan administrasi yang oleh Undang-Undang PPLH memiliki ancaman pidana melalui perumusan delik pidana formal. Sanksi pidana memang memberikan efek jera bagi pelaku pengrusakan lingkungan, yang mana sanksi tersebut berupa pidana penjara, ataupun denda. Sanksi pidana tersebut mempunyai batasan-batasa diantaranya ${ }^{18}$ :

a. Apabila dilihat dari sifat dan fungsi pemidanaan selama ini, yaitu pemidanaan individual atau personal dan bukan pemidanaan yang bersifat struktural atau fungsional. Pemidanaan yang bersifat individual atau personal kurang memberikakan efek jera pada sisi lain yang berhubungan erat secara struktural atau fungsional dengan perbuatan (dan akibat perbuatan) dari si pelaku;

${ }^{15}$ Mas Achmad Santosa, Good Governance \& Hukum Lingkungan, Jakart, ICEL, 2001 hlm. 248.

${ }^{16}$ J.B.J.M. ten Berge, Besturen door de Overheid, Deventer, W.E.J. Tjeenk Willink, 1996.

17 Barda Nawawi Arief, Bunga Rampai Kebijakan Hukum Pidana, Bandung, Citra Aditya Bakti, 1996. 
b. Sanksi pidana sangat kaku dan terbatasnya jenis pidana (sebagai obat/remidium) yang dapat dipilih untuk memidana terdakwa. Tidak seperti penegakan Hukum Administrasi yang sifatnya lebih fleksibel, Tidak sedikit dalam perundang-undangan selama ini digunakan sistem perumusan sanksi pidana yang sangat kaku dan bersifat imperatif seperti perumusan sanksi pidana secara tunggal dan komulatif.

Maka dari itu penulis berpendapat, bahwa implementasi sanksi administratif dalam penegkan hukum lingkungan diberlakukan terlebih dahulu, apabila tujuan yang hendak dicapai dari pemberian sanksi adalah untuk pemulihan fungsi lingkungan hidup ataupun perbaikan pada kerusakan lingkungan hidup akan lebih efektif apabila yang diberlakukan adalah sanksi administratif. Karena tujuan dari sanksi pidana bukanlah untuk mengembalikan fungsi dari lingkungan hidup tetapi hanya untuk memberikan efek jera dan hanya menyasar kepada subjek hukum individu, karena pada faktanya sanksi pidana dalam hukum lingkumngan dirasakan masih sangat jauh dalam menghukum korporasi sebagai subjek tindak pidana lingkungan hidup. Selain itu sanksi administratif dipandang lebih efektif karena dalam penegakan hukumnya dapat dilaksanakan oleh organ atau badan pemerintah yang khusus memiliki tugas, wewenang, serta fungsinya dalam bidang lingkungan hidup sehingga sumber daya manusia yang ada dalam organ pemerintahan tersebut memamng berkompeten dalam bidang lingkungan hidup. Berbeda dengan sanksi pidana dimana aparat penegak hukumnya yang dilaksanakan oleh kepolisian dimana tidak secara khusus menangani permsalahan lingkungan hidup, dan perkara yang ditempuh memiliki estimasi waktu yang cukup lama serta dengan biaya yang tidak sedikit.

\section{KESIMPULAN}

Efektifitas sanksi pidana dalam penegakan lingkungan hidup menurut penulis dirasakan masih sangat tidak efektif dibandingkan dengan sanksi administratif, karena sanksi administratif bertujuan untuk pemulihan fungsi lingkungan hidup ataupun perbaikan pada kerusakan lingkungan hidup akan lebih efektif apabila yang diberlakukan adalah sanksi administratif. Karena tujuan dari sanksi pidana bukanlah untuk mengemblaikan fungsi dari lingkungan hidup tetapi hanya untukm membuat efek jera dan hanya untuk subjek hukum individu, karena pada faktanya sanksi pidana dalam hukum lingkumngan dirasakan masih sangat jauh dalam menghukum korporasi sebagai subjek tindak pidana lingkungan hidup. Sehingga lebih efektif apabila sanksi administratif yang diterapkan dalam penegakan lingkungan hidup.

\section{DAFTAR PUSTAKA}

Aden, Jean Bush. "The relevance of environmental protection in Indonesia." Ecology LQ 4 (1974): 987.

Agus Widodo, Implementation Of Act No. 32 Of 2009 On Enviromental Management, International Journal of Business, Economic and Law, Vol. 10, Issue 4. 2016.

Amiq, Bachrul., Administratif Sanction In Enviromental Law, International Journal Of Research Granthaalayah, Vol. 6 June 2018.

Araya, Yulanto. "Penegakan Hukum Lingkungan Hidup di Tengah Pesatnya Pembangunan Nasional." [41] Jurnal Legislasi Indonesia 10.1 (2013). 
Vol. 1 No. 2 Juli 2019

Brent Fisse dan Jhon Braithwaite, Corporations, Crime, and Accountability, Cambridge University Press 1993.

Duff, Antony, and David Garland. "A reader on punishment." (1994). University Press, Oxford.

Erwin, Muhammad. "Hukum Lingkungan: dalam sistem perlindungan dan pengelolaan lingkungan hidup di indonesia.",Refika Aditama, Bandung, 2015.

Indonesia Center For Environmental Law (ICEL) dan Pusat Pendidikan dan Pelatihan Teknis Peradilan Mahkamah Agung, Republik Indonesia, 2014.

J.B.J.M. ten Berge, Besturen door de Overheid, Deventer, W.E.J. Tjeenk Willink, 1996

Mas Achmad Santosa, Good Governance \& Hukum Lingkungan .

P.A.F Lamintang dikutip dalam Widayati, Lidya Suryani. "Ultimum Remedium dalam Bidang Lingkungan Hidup." Jurnal Fakultas Hukum UII 22.1 (2015): 1-24.

Sherry Arnstein, Ladder of Citizen Participation, Journal Of the Amrican Institute of Palnners, November, 2007.

Suhartono, Slamet. "Corporate responsibility for environmental crime in Indonesia." Journal of Law and Conflict Resolution 9.1 (2017): 1-8.

Wibisana, Andri G. "Kejahatan Lingkungan Oleh Korporasi: Mencari Bentuk Pertanggungjawaban Korporasi Dan Pemimpin/Pengurus Korporasi Untuk Kejahatan Lingkungan Di Indonesia?." Jurnal Hukum \& Pembangunan 46.2 (2016): 149-195. 